\title{
Sylwia Wiśniewska
}

Cracow University of Economics

e-mail: sylwia.wisniewska@uek.krakow.pl

ORCID: 0000-0003-4760-2634

\section{Kamil Wiśniewski}

The Jan Kochanowski University in Kielce e-mail: kamil.wisniewski@ujk.edu.pl

ORCID: 0000-0002-4708-4163

SOFT COMPETENCIES AND EMPLOYABILITY

OF VOCATIONAL SCHOOL GRADUATES THE PERSPECTIVE OF EMPLOYERS FROM THE ŚWIĘTOKRZYSKIE VOIVODESHIP*

KOMPETENCJE MIECKKIE A ZATRUDNIALNOŚĆ ABSOLWENTÓW SZKÓL ZAWODOWYCH - PERSPEKTYWA ŚWIĘTOKRZYSKICH PRACODAWCÓW

DOI: $10.15611 / \mathrm{pn} .2019 .9 .18$

JEL Classification: J24, J40

\begin{abstract}
Summary: The aim of the article is to determine the importance of soft competencies in developing the employability of vocational school graduates in the opinion of employers from the Świętokrzyskie Voivodeship. The article presents literature studies and analyzes the results of empirical research using the IBM Predictive Solution 5. The study shows the essence of soft competencies and employability as well as the specificity of vocational education in the context of contemporary labour market requirements. The next part of the article presents the methodological assumptions of the research and the research sample statistics. The last part of the article discusses the results of surveys carried out among enterprises from the Świętokrzyskie Voivodeship. The final part of the article indicates the limitations of the completed tests and the directions of further research in the discussed area.
\end{abstract}

Keywords: soft competency, employability, vocational education, Świętokrzyskie Voivodeship.

* Paper funded from the Ministry of Science and Higher Education funds, assigned to the Faculty of Management of Cracow University of Economics, for research conducted by young academics and PhD students. 


\begin{abstract}
Streszczenie: Celem artykułu jest określenie znaczenia kompetencji miękkich w rozwijaniu zatrudnialności absolwentów szkół zawodowych w opinii świętokrzyskich pracodawców. Na potrzeby artykułu przeprowadzono studia literatury przedmiotu oraz dokonano analizy wyników badań empirycznych z wykorzystaniem pakietu IBM Predictive Solution 5. Na początku opracowania ukazano istotę kompetencji miękkich oraz zatrudnialności, a także specyfikę szkolnictwa zawodowego w kontekście wymagań współczesnego rynku pracy. Następnie zaprezentowano założenia metodyczne badań oraz dokonano charakterystyki próby badawczej. Omówiono także wyniki badań sondażowych zrealizowanych wśród przedsiębiorstw z województwa świętokrzyskiego. Na zakończenie wskazano ograniczenia zrealizowanych badań oraz kierunki dalszych badań w omawianym obszarze.
\end{abstract}

Słowa kluczowe: kompetencje miękkie, zatrudnialność, szkolnictwo zawodowe, województwo świętokrzyskie.

\title{
1. Introduction
}

Both the source subject literature and economic practice point to the quality of human capital - and employing that capital in the labour market - as a crucial factor in the socio-economic development of countries and regions. Employers are more and more aware of the significance of employee competencies in today's highly competitive markets, both nationally and globally. An essential link in the system of preparing competent workers for the economy are vocational schools. Currently in Poland actions are being taken with the aim of improving the quality and availability of vocational training, following years of its marginalization and depreciation in favour of general education. Analysis results show that the educational output of vocational schools in Poland does not meet the labour market requirements. Adapting to the employers' needs constitutes a challenge for vocational schools. The maladjustment of the educational output results in the inadequacy of vocational school leavers' competencies with respect to the requirements of the contemporary labour market.

The results of the empirical research indicate that regardless of the job position employers expect soft competencies. The report entitled "The Balance of Human Capital" emphasized that the issue of mismatched competencies is mainly related to soft competencies such as communication (oral and written), teamwork, adaptability, goal orientation and influencing others [Kocór 2015]. Soft competencies and command of foreign languages also prevail in the list of the most desirable competencies prepared by Hays Polska for "Forbes" [Domaradzki 2015]. The importance of soft competencies is also confirmed by the results of the local research, according to which employers seek employees with the following competencies: building and maintaining contacts with other people, communication, teamwork [Wojewódzki Urząd Pracy w Krakowie 2015], adaptability to new situations, quick learning skills, readiness and willingness to cooperate and the ability to assess the problem from different perspectives [Wojewódzki Urząd Pracy w Krakowie 2018]. 
Importantly, the level of competencies, including soft competencies, is deemed as the basic determinant of employability in the modern labour market.

With respect to the premise presented above, the purpose of the article is to determine the importance of soft competencies in developing employability of vocational school graduates in the opinion of employers from the Świętokrzyskie Voivodeship. For the purpose of the article, the subject literature were studied and the research results of the survey conducted among companies from the Świętokrzyskie Voivodeship were analysed. The statistical analysis was performed with the use of IBM Predictive Solution 5.

\section{Literature review}

\subsection{Soft competencies}

As a result of the analysis of the subject literature, the authors noted that there is a multitude of definitions of the concept of 'competencies', which confirms the multidimensional nature of the issue undertaken by the authors. This problem is considered from many perspectives: national, sectoral, organizational (the resource-based view), individual (mainly in the context of education) and human resource management [Holtkamp, Jokinen, Pawlowski 2015; Stor, Kupczyk 2015]. The essence of competencies in the area of human resource management is reflected in the definition developed by Pocztowski [2018]. According to his interpretation, competencies constitute a system of permanent values/characteristics of an individual, which is a configuration of knowledge, skills, abilities, motives and values, which provides highly efficient effects and other above-average achievements in a specific area and in the context of professional activity.

Both the subject literature and the business practice commonly apply the distinction between soft and hard competencies (cf. [Jacobs 1989; Skulmoski, Hartman 2010; Sisson, Adams 2013; Fattahi et al. 2014; Holtkamp, Jokinen, Pawlowski 2015; Torres, Gregory 2018; Pang et al. 2019]). In general, soft competencies are defined as "personal behaviour or attitudes" [Rosas, Macedo, Camarinha-Matos 2009]. Nowadays it is emphasized that soft competencies are complementary in relation to hard competencies and that they play a significant role in human resource management. Their growing importance in improving organizational effectiveness and sustainable economic growth is indicated as well [Ayyakkannu 2018].

Soft competencies include personal and social competencies, therefore they ensure effective self-management - personal competencies as well as high interpersonal efficiency - social competencies. They are useful in any workplace and determine successful professional development. They belong to the group of transferable competencies, i.e. those which are crucial for the lifelong learning process, as well as for the development and effective use of other competencies in various areas of professional and private life [Osiński 2010; Alsabbah, Ibrahim 2013; 
Sisson, Adams 2013]. Personal competencies can include: creativity, loyalty, assertiveness, responsibility, flexibility, problem solving, dealing with stress, decision making, analytic thinking, and own work organization. In contrast, examples of social competencies are: oral communication, written communication, interpersonal awareness, teamwork, network building, personal culture, negotiating, developing others, influencing and empowering others [Lantelme, Formoso, Powell 2017; Ballesteros-Sánchez, Ortiz-Marcos, Rodríguez-Rivero 2019].

\subsection{Employability}

The concept of employability is gaining importance due to the growing uncertainty and flexibility of employment, the growing competency gap, dynamism and unpredictability of career paths and other changes taking place in the modern labour market (cf. [Pauli 2015; Wiśniewska 2015; Magnano et al. 2019; Peeters et al. 2019; van der Heijden, Spurk 2019]). The term 'employability' was used for the first time by W.H. Beveridge [1909]. Employability is understood as "the ability to be employed", "the ability to find employment", "an employment potential" or "a career potential” (cf. [van der Heijde, van der Heijden 2006; Świgoń 2014]).

Table 1. An overview of definitions of the concept of employability

\begin{tabular}{|l|l|}
\hline \multicolumn{1}{|c|}{ Authors } & \multicolumn{1}{c|}{ Definitions } \\
\hline $\begin{array}{l}\text { Van der Heijde, } \\
\text { Van der Heijden } \\
\text { [2006] }\end{array}$ & $\begin{array}{l}\text { "The continuous fulfilling, acquiring or creating of work through the optimal } \\
\text { use of competences". }\end{array}$ \\
\hline $\begin{array}{l}\text { Rothwell, Arnold } \\
\text { [2007] }\end{array}$ & "The ability to keep the job one has or to get the job one desires". \\
\hline CEDEFOP [2008] & $\begin{array}{l}\text { "The combination of factors which enable individuals to progress towards or get } \\
\text { into employment, to stay in employment and to progress during their career". }\end{array}$ \\
\hline $\begin{array}{l}\text { Council of the } \\
\text { European Union }\end{array}$ & $\begin{array}{l}\text { "The combination of factors which enable individuals to progress towards or } \\
\text { enter employment, to stay in employment and to progress during their career } \\
\text { - is a complex concept, involving not only each individual's characteristics, } \\
\text { skills, attitudes and motivation, but also other external factors which lie beyond } \\
\text { the scope of education and training policy, such as labour market regulations, } \\
\text { demography, the structure of the economy and the overall economic situation". }\end{array}$ \\
\hline Świgoń [2014] & $\begin{array}{l}\text { An employee's ability to cope in the internal and external labour market, related } \\
\text { to among others the ability to anticipate and adapt to continuous changes in } \\
\text { the labour market which results from technological development and macro- } \\
\text { economic conditions. }\end{array}$ \\
\hline $\begin{array}{l}\text { Vanhercke et al. } \\
\text { [2014] }\end{array}$ & $\begin{array}{l}\text { "The individual's perception of his or her possibilities of obtaining and } \\
\text { maintaining employment". }\end{array}$ \\
\hline Marzec [2015] & $\begin{array}{l}\text { Specific features of individuals thanks to which they are able to identify and } \\
\text { pursue career opportunities both in the internal and external labour market. }\end{array}$ \\
\hline
\end{tabular}

Source: own study on the basis of the analysis of the subject literature. 
The authors selected definitions and interpretations of the concept of employability and presented them in Table 1. The above definitions share some common elements. They display a variety of factors affecting employability, which are related to both the character features of a particular person and the educational system, the labour market or the social and economic situation. They also emphasize the importance of the constant development of the level of competencies.

It is worth emphasizing that employability is determined by many factors, which include demand, supply and mixed factors (demand and supply). Demand factors include the volume of the demand for labour, the capacity of the labour market or the attitude of employers towards the unemployed. Supply factors include the volume of the labour supply, as well as organizational and individual factors. However, the structure and the labour market policy might be regarded as mixed factors. A crucial issue is that basic individual factors include competencies [Wiśniewska 2015].

\subsection{Vocational education}

The effective operation of the labour market requires balancing the two structures supply and demand - in terms of professions and competency requirements. However, empirical research shows that in Poland this is far from satisfactory [Zawłocki, Niewiadomski 2016]. An essential link in the system of preparing competent workers for the economy are vocational schools. The essence of vocational education entails seeking ways to move from identifying the initial level to the desired level of vocational competencies [Drzeżdżon 2009].

In the area of pedagogy, vocational education is defined as a process aiming at equipping students with specific knowledge and skills in the areas of industry, agriculture and breeding livestock, and services. This process entails transmitting general knowledge and specialized practical skills which will enable the students to work in their chosen profession. Vocational education results in a National Vocational Qualification in the chosen area [Kupisiewicz, Kupisiewicz 2009].

Creating conditions for the growth of modern vocational education is an urgent, yet long-term, task. It requires the cooperation of educational authorities of all levels, as well as entrepreneurs, community partners and the schools themselves. This task is hindered by the marginalization of vocational education that has been experienced [Drzeżdżon 2009]. Both in Poland and in the Świętokrzyskie Voivodeship, a significant decline in the popularity of vocational schools has been observed for a long time. As a consequence, year after year increasingly fewer people select this type of school. The reasons include : the low quality of the educational offer of vocational schools, mismatched curricula in comparison with the expectations of employers from particular industries, conviction about the elitism of higher education and its superiority over vocational education, as well as insufficient career counselling and promotion of vocational education [Sobierajski 2013; Zubek 2015]. 
This situation adversely affects the labour market in which the demand for vocational school graduates is constantly growing, while the market is saturated with university graduates [Ziółkowska, Malarski 2013; Główny Urząd Statystyczny 2018].

\section{Methodology and research sample}

The purpose of the research was to determine the importance of soft competencies in developing the employability of vocational school graduates in the opinion of employers from the Świętokrzyskie Voivodeship. The research assumes the following hypothesis: soft competencies are important for developing the employability of vocational school graduates. For the purpose of the research, it was assumed that soft competencies constitute attitudes and behaviours manifested in interpersonal relations, as well as attitudes and behaviour related to self-management which affect the achievement of above-average results in the workplace. It was also assumed that employability is an ability of a particular person to take up, maintain and change employment as well as to develop a professional career (both in the internal and external labour market) thanks to the optimal use of their competencies.

Secondary and primary sources of information were used to achieve the assumed research purpose and to verify the research hypothesis. First, studies of the subject literature were carried out to serve as a theoretical basis for empirical analyses. In order to obtain information from primary sources, the authors conducted surveys using the technique of a questionnaire interview: a direct (CAPI - Computer Assisted Personal Interview) and telephone (CATI - Computer Assisted Telephone Interview) interview. The research is idiographic, therefore the conclusions can only be generalised on the research sample. The conclusions cannot be generalized beyond the research population due to the lack of sampling procedures. The research tool was the interview questionnaire developed by the authors on the basis of the analysis of existing data. The interview questionnaire mainly included closed questions in the form of the so-called table questions or scale questions. IBM Predictive Solution 5 was used to analyse the data.

An intentional choice of the study sample was applied in the research, in which 150 enterprises were included in the direct interviews, whereas the telephone interviews were conducted on a sample group comprising 500 companies. The research was conducted between June and August 2016 as part of the project entitled "Modern Vocational School - a Modern Region" co-financed by the European Union from the European Social Fund as part of the Regional Operational Programme for the Świętokrzyskie Voivodeship for the period 2014-2020. The territorial scope of the research covered the Świętokrzyskie Voivodeship. The studied companies operated in all the counties ('powiat') of the Świętokrzyskie Voivodeship.

When characterizing the studied population, it is worth mentioning that the dominant group included micro $(62.2 \%)$ and small $(25.2 \%)$ enterprises, while the least numerous group was large enterprises (2.9\%). Medium-sized enterprises 
constituted $9.7 \%$ of the study sample. It is noteworthy that the structure of respondents corresponds to the structure of enterprises operating both in the Świętokrzyskie Voivodeship and in Poland. Micro and small enterprises prevail in terms of quantity both in the Świętokrzyskie Voivodeship and in Poland. The majority of the studied enterprises started operating in 2000 and later (62.5\%). The largest group among the analysed enterprises included those enterprises which were established in the period between 2005 and 2009 (24.5\%), whereas the least numerous group included those enterprises which were established between 1945-1964 (2.8\%). It is worth emphasizing that the longest operating enterprises among the respondents were set up before 1945 .

\section{Research results and discussion}

The subject matter of the research included the soft competencies of vocational school graduates. As part of the research, the following soft competencies were analysed: motivation to work, loyalty, punctuality, communication, availability, creativity, initiative, flexibility, entrepreneurship, multitasking, self-organization, consistent actions, analytical thinking, readiness to learn, teamwork, and working in a team with a varied age structure (Table 2).

Table 2. Soft competencies - descriptive statistics

\begin{tabular}{|l|c|c|c|}
\hline \multicolumn{1}{|c|}{ Specification } & Mean (M) & $\begin{array}{c}\text { Standard } \\
\text { deviation (SD) }\end{array}$ & $\begin{array}{c}\text { The number } \\
\text { of respondents } \\
(\mathrm{N})\end{array}$ \\
\hline Motivation to work & 4.59 & .821 & 650 \\
\hline Punctuality & 4.56 & .807 & 650 \\
\hline Readiness to learn & 4.53 & .791 & 650 \\
\hline Teamwork & 4.53 & .800 & 650 \\
\hline Loyalty & 4.51 & .857 & 650 \\
\hline Consistent actions & 4.51 & .835 & 650 \\
\hline Communication & 4.47 & .825 & 650 \\
\hline Self-organization & 4.47 & .872 & 650 \\
\hline Working in a team with varied & & & 650 \\
\hline age structure & 4.47 & .842 & 650 \\
\hline Availability & 4.41 & .849 & 650 \\
\hline Creativity & 4.38 & .907 & 650 \\
\hline Initiative & 4.37 & .875 & 650 \\
\hline Flexibility & 4.35 & .899 & 650 \\
\hline Analytical thinking & 4.31 & .982 & 650 \\
\hline Entrepreneurship & 4.21 & 1.017 & 650 \\
\hline Multitasking & 4.20 & 1.005 & \\
\hline
\end{tabular}

Source: own study on the basis of own research. 
Among the studied soft competencies, with the help of the conducted factor analysis based on the method of main components with Varimax rotation, one factor was distinguished (Table 3).

Table 3. Soft competencies - matrix of rotated compounds

\begin{tabular}{|l|c|}
\hline \multicolumn{1}{|c|}{ Specification } & Compound \\
\hline Consistent actions & .868 \\
\hline Self-organization & .857 \\
\hline Initiative & .848 \\
\hline Motivation to work & .842 \\
\hline Working in a team with varied age structure & .835 \\
\hline Teamwork & .834 \\
\hline Punctuality & .833 \\
\hline Flexibility & .826 \\
\hline Creativity & .817 \\
\hline Availability & .811 \\
\hline Loyalty & .808 \\
\hline Communication & .804 \\
\hline Readiness to learn & .801 \\
\hline Analytical thinking & .791 \\
\hline Entrepreneurship & .761 \\
\hline Multitasking & .757 \\
\hline
\end{tabular}

Source: own study on the basis of own research.

The analysis of internal reliability measured with the use of Cronbach's alpha amounts to 0.966 with correlations of positions greater than or equal to 0.73 . This makes it possible to embrace the statement that all aspects measure the same latent variable which is soft competencies. In this event, the data obtained using the ANOVA test with repeatable measurement may be analysed.

As a result of the ANOVA analysis with repeatable measurement, the test of inter-object effects was completed with the following result: $\mathrm{F}(1.649)=25028.905$, $\mathrm{P}<0.001, \mathrm{~h} 2=.975$. According to the test results, there are differences between particular competencies. The post hoc analysis with the Bonferroni correction indicated that there are four groups of competencies with statistically significant differences:

1. Motivation to work, punctuality, teamwork, readiness to learn, loyalty.

2. Consistent actions, communication, self-organization, working in a team with varied age structure.

3. Availability, creativity, initiative, flexibility.

4. Entrepreneurship, multitasking.

There are no differences between competencies within each group. 
As part of the research, not only soft competencies but also hard competencies (general and specialised) were analysed. An average assessment of the importance of soft competencies for the employability of vocational school graduates was analysed in comparison with hard competencies. Table 4 includes a summary of the values achieved by particular types of competencies (general vocational, specialised vocational and soft competencies). The obtained results show that soft competencies are the most relevant in terms of the employability of vocational school graduates $(\mathrm{M}=4.4529 ; \mathrm{SD}=0.7083)$, followed by general vocational competencies $(\mathrm{M}=4.1609 ; \mathrm{SD}=0.813)$, while third place is taken by specialised vocational competencies $(\mathrm{M}=3.9153 ; \mathrm{SD}=0.8709)$. At the same time, it is worth noting that the analysis of correlations conducted with the use of the Pearson correlation coefficient indicates that there is a significant moderate relationship between particular competencies which means that it is not possible to develop individual competencies in isolation from the others.

Table 4. Competencies - descriptive statistics

\begin{tabular}{|l|c|c|c|}
\hline \multicolumn{1}{|c|}{ Specification } & Mean (M) & $\begin{array}{c}\text { Standard deviation } \\
\text { (SD) }\end{array}$ & $\begin{array}{c}\text { The number } \\
\text { of respondents } \\
(\mathrm{N})\end{array}$ \\
\hline Soft competencies & 4.4529 & .70833 & 650 \\
\hline General vocational competencies & 4.1609 & .81299 & 650 \\
\hline Specialised vocational competencies & 3.9153 & .87094 & 650 \\
\hline
\end{tabular}

Source: own study on the basis of own research.

In the course of the research, the authors conducted an analysis of the average assessment of the importance of soft competencies for the employability of vocational school graduates in a division according to the size of enterprises. On the basis of the analyses, it can be concluded that soft competencies are the most important for the employability of vocational school graduates from the point of view of medium-sized enterprises $(\mathrm{M}=4.52 ; \mathrm{SD}=0.647)$. However, they have the lowest importance in the opinion of large enterprises $(M=4.29 ; \mathrm{SD}=0.595)$. In order to verify the statistical significance of these differences, a one-way ANOVA analysis was performed. Its result $\mathrm{F}(3.649)=0.584 ; \mathrm{p}=0.626$ indicates that there are no statistically significant differences between the size of enterprises in terms of the assessment of the importance of soft competencies. The differences between the size of enterprises are not statistically significant and result from a measurement error. The obtained results show that the size of enterprises does not affect the perception of the importance of soft competencies in terms of the employability of vocational school graduates. This means that micro-enterprises assess their significance and importance in the same way as small, medium or large ones (Table 5). 
Table 5. Soft competencies - descriptive statistics

\begin{tabular}{|l|c|c|c|}
\hline \multicolumn{1}{|c|}{ Specification } & Mean (M) & $\begin{array}{c}\text { Standard deviation } \\
\text { (SD) }\end{array}$ & $\begin{array}{c}\text { The number } \\
\text { of respondents } \\
(\mathrm{N})\end{array}$ \\
\hline Medium enterprises & 4.5240 & .64677 & 63 \\
\hline Micro enterprises & 4.4569 & .71708 & 404 \\
\hline Small enterprises & 4.4344 & .72309 & 164 \\
\hline Large enterprises & 4.2908 & .59452 & 19 \\
\hline
\end{tabular}

Source: own study on the basis of own research.

It is worth noting that the obtained results refer to the research conclusions presented in the subject literature. They indicate that soft competencies belong to the most desirable competencies in the modern labour market (cf. [Alsabbah, Ibrahim 2013; Fattahi et al. 2014; Holtkamp, Jokinen, Pawlowski 2015; Lantelme, Formoso, Powell 2017; Torres, Gregory 2018; Ballesteros-Sánchez, Ortiz-Marcos, Rodríguez-Rivero 2019; Pang et al. 2019]).

\section{Conclusions, limitations and future research}

The conclusions which result from the conducted research indicate that the studied examples of employers from the Świętokrzyskie Voivodeship highly appreciate the importance of soft competencies in developing the employability of vocational school graduates. Top ranked soft competencies include: motivation to work, punctuality, readiness to learn, teamwork, loyalty, consistent actions, communication, self-organization and working in a team with varied age structure. With regard to the adopted hypothesis, it is worth noting that the hypothesis was verified as true and that in the opinion of employers from the Swiętokrzyskie Voivodeship, soft competencies are more important than hard competencies in the context of the employability of vocational school graduates. The obtained results refer to the conclusions drawn on the basis of the research conducted in the analysed field presented in the subject literature. The research on the expectations of employers towards employees regarding competencies indicate the growing importance of soft competencies in the modern labour market.

To conclude, the limitations of these studies need to be presented. They mainly refer to the selection and size of the research sample. The territorial scope, the Świętokrzyskie Voivodeship, constitutes also a limitation of the completed research. However, one should also stress the fact that the research results are the basis for indicating the directions of further research related to the analysis of competencies of vocational school graduates and the expectations of employers regarding competencies. In the course of further research, such expectations of employers need to be compared with the level of competencies acquired by vocational school graduates. It also seems reasonable to conduct research on a national (including the 
possibility to compare the results obtained in particular voivodeships) and international basis, as well as in respects of sectors of industry. Hence it will be also possible to specify the obtained results. The results of the suggested research may serve as an inspiration for teachers and students of vocational schools regarding competencies which should be developed especially in the process of vocational education. As a consequence of the research and analyses, selected decision problems related to the operation of the modern labour market can be optimised.

\section{Bibliography}

Alsabbah M.Y.A., Ibrahim H.I., 2013, Employee competence (soft and hard) outcome of recruitment and selection process, American Journal of Economics, vol. 3, no. C, pp. 67-73.

Ayyakkannu A., 2018, Technical and soft skill competencies mapping at the entry level of diploma holders in mechanical and automobile engineering for auto and auto components industries, International Journal of Mechanical and Production Engineering Research and Development, vol. 8, no. 1, pp. 1209-1220.

Ballesteros-Sánchez L., Ortiz-Marcos I., Rodríguez-Rivero R., 2019, The impact of executive coaching on project managers' personal competencies, Project Management Journal, vol. 50, no. 3, pp. 306-321.

Beveridge W.H., 1909, Unemployment. A Problem of Industry, Longmans, Green\& Co., London.

CEDEFOP, 2008, Terminology of European education and training policy. A selection of 100 key terms, Office for Official Publications of the European Communities, Luxembourg.

Council of the European Union, 2012, Conclusions on the employability of graduates from education and training, Official Journal of the European Union, C169/04.

Domaradzki K., 2015, 10 najbardziej pożadanych kompetencji w 2016 roku, Forbes, https://www. forbes.pl (17.07.2019).

Drzeżdżon W., 2009, Kształcenie zawodowe w kontekście potrzeb polskiego i europejskiego rynku pracy. Wybrane zagadnienia, Studia Gdańskie. Wizje i Rzeczywistość, t. VI, pp. 38-53.

Fattahi B., Milanovich N., Howes S., Paccaloni G., Brett F., 2014, Soft competency development as a global challenge, Journal of Petroleum Technology, vol. 66, no. 10, pp. 136-141.

Główny Urząd Statystyczny, Urząd Statystyczny w Gdańsku, 2018, Oświata $i$ wychowanie w roku szkolnym 2017/2018, Warszawa-Gdańsk.

Heijde C.M. van der, Heijden B.I.J.M. van der, 2006, A competence-based and multidimensional operationalization and measurement of employability, Human Resource Management, vol. 45, no. 3, pp. 449-476.

Heijden B. van der, Spurk D., 2019, Moderating role of LMX and proactive coping in the relationship between learning value of the job and employability enhancement among academic staff employees, Career Development International, vol. 24, no. 2, pp. 163-186.

Holtkamp P., Jokinen J.P.P., Pawlowski J.M., 2015, Soft competency requirements in requirements engineering, software design, implementation, and testing, The Journal of Systems and Software, vol. 101, no. C, pp. 136-146.

Jacobs R., 1989, Getting the measure of managerial competence, Personnel Management, vol. 21, no. 6, pp. 32-37.

Kocór M., 2015, Niedopasowanie kompetencyjne, [w:] Górniak J. (ed.), Polski rynek pracy - wyzwania i kierunki działań. Na podstawie badań Bilans Kapitału Ludzkiego 2010-2015, PARP, WarszawaKraków. 
Kupisiewicz Cz., Kupisiewicz M., 2009, Stownik pedagogiczny, Wydawnictwo Naukowe PWN, Warszawa.

Lantelme E.M.V., Formoso C.T., Powell J.A., 2017, Integrating technical and social competencies of construction managers, Journal of Professional Issues in Engineering Education and Practice, vol. 143 , no. 4.

Magnano P., Santisi G., Zammitti A., Zarbo R., Di Nuovo S., 2019, Self-perceived employability and meaningful work. The mediating role of courage on quality of life, Sustainability, no. 11(764), pp. 1-14.

Marzec I., 2015, Uwarunkowania rozwoju zatrudnialności pracowników w organizacji, Wydawnictwo Uniwersytetu Ekonomicznego w Katowicach, Katowice.

Osiński Z., 2010, Kompetencje miękkie absolwenta humanistycznych studiów wyższych a metody prowadzenia zajęć, [in:] Sitarska B., Jankowski K., Droba R. (eds.), Studia wyższe z perspektywy rynku pracy, Wydawnictwo Akademii Podlaskiej, Siedlce.

Pang E., Wong M., Leung C.H., Coombes J., 2019, Competencies for fresh graduates'success at work. Perspectives of employers, Industry and Higher Education, vol. 33, no. 1, pp. 55-65.

Pauli U., 2015, Working in SMEs as a way to improve employability, Human Resource Management, no. 6(107), pp. 97-110.

Peeters E., Nelissen J., De Cuyper N., Forrier A., Verbruggen M., De Witte H., 2019, Employability capital. A conceptual framework tested through expert analysis, Journal of Career Development, vol. 46, no. 2, pp. 79-93.

Pocztowski A., 2018, Zarzqdzanie zasobami ludzkimi. Koncepcje, praktyki, wyzwania, PWE, Warszawa.

Rosas J., Macedo P., Camarinha-Matos L.M., 2009, An organization's extended (soft) competencies model, [in:] Camarinha-Matos L.M., Paraskakis I., Afsarmanesh H. (eds.), Leveraging Knowledge for Innovation in Collaborative Networks. PRO-VE 2009. IFIP Advances in Information and Communication Technology, vol. 307, Springer, Berlin, Heidelberg.

Rothwell A., Arnold J., 2007, Self-perceived employability. Development and validation of a scale, Personnel Review, vol. 36, no. 1, pp. 23-41.

Sisson L.G., Adams A.R., 2013, Essential hospitality management competencies. The importance of soft skills, Journal of Hospitality \& Tourism Education, vol. 25, no. 3, pp. 131-145.

Skulmoski G.J., Hartman F.T., 2010, Information systems project manager soft competencies. A project-phase investigation, Project Management Journal, vol. 41, no. 1, pp. 61-80.

Sobierajski T., 2013, Kształcenie zawodowe w postindustrialnej gospodarce. Demografia, Grupowanie, Klasyfikacja, Doradztwo, Krajowy Ośrodek Wspierania Edukacji Zawodowej i Ustawicznej, Warszawa.

Stor M., Kupczyk T., 2015, Differences in competency management. Comparative analysis between Polish, Spanish, and Austrian business practices, Journal of Intercultural Management, vol. 7, no. 2, pp. 49-74.

Świgoń M., 2014, Potencjat kariery studentów kierunków i specjalności informatologicznych, Teraźniejszość-Człowiek-Edukacja, nr 66(2), pp. 79-90.

Torres E.N., Gregory A., 2018, Hiring manager's evaluations of asynchronous video interviews. The role of candidate competencies, aesthetics, and resume placement, International Journal of Hospitality Management, vol. 75, pp. 86-93.

Vanhercke D., De Cuyper N., Peeters E., Witte H. de, 2014, Defining perceived employability. A psychological approach, Personnel Review, vol. 43, no. 4, pp. 592-605.

Wiśniewska S., 2015, Development of employee competencies as a determinant of employability in the modern labour market, Human Resource Management, no. 6(107), pp. 131-143.

Wojewódzki Urząd Pracy w Krakowie, 2015, Pracodawca - rynek - pracownik. Badanie zapotrzebowania na pracowników wśród małopolskich pracodawców 2014, Kraków. 
Wojewódzki Urząd Pracy w Krakowie, 2018, Rynek pracy w Małopolsce 2017. Ocena sytuacji na rynku pracy województwa małopolskiego 2017, Kraków.

Zawłocki I., Niewiadomski K., 2016, Optymalne ścieżki kształcenia prowadzqce do uzyskania petnych kompetencji zawodowych, Edukacja-Technika-Informatyka, nr 4(18), pp. 164-169.

Ziółkowska P., Malarski M., 2013, Analiza oferty edukacyjnej szkół zawodowych w kontekście potrzeb przedsiębiorstw, FPL, Łódź.

Zubek M., 2015, Ksztatcenie zawodowe w Polsce i w regionie świętokrzyskim, [w:] Krawczyk-Blicharska M., Miko-Giedyk J., Kowalski S. (eds.), Kształcenie zawodowe w perspektywie współczesnych uwarunkowań społecznych, Uniwersytet Jana Kochanowskiego w Kielcach, Kielce. 
